\title{
Efforts To Increase Students 'Ability To Answer The Contents Dongeng Using The Indonesian Language With The How To Use Indonesian Self
}

\author{
Lailatul Maghfiroh \\ Universitas Negeri Surabaya \\ Surabaya, Indonesia \\ Aufiza.leiela@gmail.com
}

\begin{abstract}
This research is motivated by the low acquisition of learning outcomes in the Indonesian language. To find out why student performance is not as expected, of course, the teacher needs to reflect on himself to be able to find out the factors that cause students to fail in Indonesian language lessons. The research that the writer did uses a qualitative approach to the type of classroom action research. The sequence of research activities includes (1) planning, (2) implementation, (3) observation and (4) reflection. In collecting data, the author uses interview techniques, observation, documentation, measurement of learning outcomes. As for the analysis, the author uses qualitative descriptive analysis techniques. The results showed that (1) the use of Indonesian in daily communication can improve students' ability in answering the contents of fairy tales using the Indonesian language. (2) The implementation of the Indonesian language learning process related to answering the contents of fairy tales using Indonesian has shown that the learning process is going well.
\end{abstract}

\section{Keywords—Student Ability; Dongeng; Indonesian Language}

\section{INTRODUCTION}

The main function of language is as a medium of communication. We realize that the interaction and all kinds of activities in society will be paralyzed without language. Language is a medium of communication between members of the public in the form of sound symbols produced by human speech utensils[1]. Thus every citizen is required to speak language skillfully. If every citizen is skilled in speaking, then communication between citizens will take place well [2].

The low learning achievement of Indonesian language subjects in Madrasah Ibtidaiyah Nahdlatul Ulama (MINU) Kedungrejo Waru Sidoarjo indicates an indication of the low performance of student learning and the ability of teachers in managing quality learning. To find out why student achievement is not as expected, teachers need to reflect on themselves to be able to know the factors that cause the failure of students in Indonesian language lessons. As a good teacher and professional, this problem would need to be addressed immediately.

Several times the assignment of subjects in Bahasa Indonesia in answer the contents of fairy tales by using
Indonesian good and true does not show the expected level of success [3] because only 10 children from 43 students or only $23 \%$ who mastered the material, while 33 other students or 77 $\%$ still have not mastered the material.

To apply the Indonesian language usage and the rules become the basis of the correctness of the use of the language[4]. Therefore, a collection of linguistic elements needs to have a framework of reference in the Indonesian language in accordance with improved language rules [5].

Many elements affect the success of the student learning process. However, teachers are still considered the most important element and occupy a high position in the success of successful learning in school. Teachers have a responsibility to improve students' communicative abilities. To that end, teachers should automatically have a more communicative ability.

In the mastery of Indonesian learning materials that emphasize the four language skills should teachers be able to provide advice and encouragement to students[6]? On the advice and encouragement is expected the students arise passion and passionate in deepening the subject matter[7].

\section{METHOD}

The type of research used in this study is Classroom Action Research with action in the form of efforts to improve students' ability to answer the contents of fairy tales by using Bahasa Indonesia, which will be applied to the learning of Bahasa Indonesia[8]. This classroom action research uses a form of collaboration[9].

This study uses an action research model from Kurt Lewin, which is a spiral from one cycle to the next. Each cycle includes plans, actions, observations, and reflections. The next step in the cycle is the revised planning, action, observation and reflection of the previous cycle[10].

The subjects of this research are students of class III-B of Madrasah Ibtidaiyah Nahdlatul Ulama '(MINU) Kedungrejo Waru Sub-district of Sidoarjo Regency, amounting to 43 children consist of 20 male students and 23 female students. 


\section{RESEARCH RESULT}

Based on the results of the first cycle study, students have improved in using the pronunciation and intonation of speech learning. Cycle II implemented action in the form of application of the use of pronunciation and good intonation in learning Indonesian.

Based on data analysis, the most dominant activity of students in the learning process of Indonesian language is to pay attention to teacher explanation, write important matters, ask and answer questions, interested in using props. So it can be said that student activity can be actively categorized.

As for the activities of teachers during the learning process has implemented the steps in the use of props well. This can be seen from the activity of teachers that emerged such as guiding and observing activities of students in conducting activities, giving feedback or evaluation or question and answer where the percentage for the above activities is quite large.

From the findings of the research above shows that the effort to improve students 'ability to answer the contents of fairy tales by using Indonesian language in Madrasah Ibtidaiyah Nahdlatul Ulama' (MINU) Kedungrejo Waru Sidoarjo after the improvement has experienced success rate, as evidenced by the number of students who complete in learning Bahasa Indonesia .

From the results of Classroom Action Research (PTK) conducted by teachers and researchers on "Efforts to Increase Students.

\section{CONCLUSION}

'Ability in Responding to Fill the Tale by using Indonesian in Madrasah Ibtidaiyah Nahdlatul Ulama' (MINU) Kedungrejo Waru Sidoarjo". Can be concluded:

1. Ability Students in the Indonesian language can open insight understanding and deepening of Bahasa Indonesia materials well, especially speaking with good pronunciation and intonation in learning Indonesian at school. This is indicated by the student activity in answering and asking questions on the medium scale to be very good.
2. Efforts to improve the ability of students in using the Indonesian language can be achieved well, the teacher uses a fairy tale to familiarize children speak with intonation, mimic, and proper pronunciation, in addition to the fairy tale there are many vocabulary or vocabulary that more and more he read, then the more vocabulary they have, this is evidenced by the increasing activity of students in the Indonesian language is good. From the student activity scale shows an increase in symptoms from 2.5 to 3.7 .

Efforts made by teachers to improve the ability of students in answering the contents of fairy tales by using Indonesian language by getting familiar with Indonesian language proved very well received by students of class III MINU Kedungrejo Waru Sidoarjo which is shown by the increase in the Indonesian language, either through courage to express feelings, courage to answer the content of fairy tales, and also courage to ask things that are not understood. They are not hesitant to communicate using Bahasa Indonesia, they prove it with a very fantastic Indonesian score, even though there are 4 unfinished children $(9,30 \%)$ in learning. This means that $90.70 \%$ of 43 students have mastered the material well.

\section{REFERENCES}

[1] K. Darmadi and R. Nirbaya, "Bahasa Indonesia 3: untuk SD/MI kelas III,” Jakarta Pus. Perbukuan Dep. Pendidik. Nas., 2008.

[2] W. J. S. Poerwadarminta, "Kamus Bahasa Indonesia Edisi Ketiga," Jakarta: Balai Pustaka, 2007.

[3] A. Aziz and A. Majid, "Mendidik dengan cerita," Bandung: Remaja Rosdakarya, 2002.

[4] M. Muslich, Tatabentuk bahasa Indonesia: kajian ke arah tatabahasa deskriptif. Bumi Aksara, 2008.

[5] C. Abdul, "Agustina leonie," SOSIOLINGUISTIK Perkenalan Awal, 2010 .

[6] Mulyasa, Peran Guru di Sekolah. Bandung: PT. Remaja Rosdakarya, 2005 .

[7] D. Laksmi, "Strategi Pembelajaran," Jakarta Derektorat Jendral Pendidik. Islam Dep. Agama RI, 2009.

[8] N. Hamim and H. Salamah, "Penelitian Tindakan Kelas," PT. Refka Petra Media, Surabaya, 2009.

[9] S. Supardi and A. Suharsimi, "Penelitian Tindakan Kelas," Jakarta Bumi Aksara, 2009

[10] Mangkunegara, Psikologi Pendidikan. Jakarta: Rineka Cipta, 2000. 